\title{
PASTURE SPECIES AND THEIR PERFORMANCE IN THE WAIRARAPA
}

\author{
W. Rumball \\ Grasslands Division, DSIR, Palmerston North
}

\section{Summary}

\begin{abstract}
An outline is given of trials in the Wairarapa of the currently available pasture species, and also of prospective new varieties. Attempts to bleed new varieties specially suited to the dry east coast hill pastures are described. In spaced-plant trials of ryegrass and cocksfoot, the overseas material was rarely as good as that collected or bred in New Zealand, In Phalaris, however, the best lines were usually from Portugal and Australia. Most Mediterranean lines could also provide genes for winter growth. Future stages of the project are discussed.
\end{abstract}

\section{INTRODUCTION}

IN THE PAST, the Wairarapa has apparently had no special attention in the breeding of pasture plants. From time to time, however, interested persons have experimented with different species of grass and clover, and the Department of Agriculture does likewise. Indeed, at present that Department is comparing many of the familiar species, such as cocksfoot, ryegrass and tall fescue, in mowing and grazing trials. It hopes thereby to learn the strengths and weaknesses of each species under different managements and, since the results are always available to local farmers, they will not be given here. The Wairarapa is also included in the countrywide testing scheme of new varieties bred by Grasslands Division - e.g., the local division of the Department of Agriculture is currently comparing the new winter-growing white clover, 'Grasslands 4700', with the familiar 'Grasslands Huia'.

The policy of Grasslands Division is to breed varieties of wide adaptability rather than ones specifically suited to particular environments. With cross-pollinated pasture plants there are practical problems in maintaining varietal seed purity, and therefore release of a regional variety would be considered only if it were considerably superior to a variety of wide adaptability (Corkill, 1957). Currently available pasture species are considered to be reasonably suitable for the central valley and western hills of the Wairarapa. However, it was recently decided that, since the dry 
regions of eastern Hawke's Bay and the Wairarapa had droughts too often and too severe to allow much production from the existing varieties of grass and clover, an attempt would be made to locate or breed some better plants. Accordingly, Grasslands Division recently obtained the use of one acre of stony terrace on the Wairarapa Cadet Training Farm (about five miles south of Masterton) and began screening a wide range of grasses. Details of the experiment and the generalized results are given below.

\section{EXPERIMENTAL}

Although the experimental site receives about 35 in. of rain per year, compared with about 30 in. in parts of the eastern hills (Report, 1968), this amount falls mainly in the winter, and drains rapidly through the stony soil. In the past two years the February. March rain has been down to 1.36 in, and 1.83 in. The yearly temperature averages about $54^{\circ} \mathrm{F}$ but it ranges from severe frosts in the winter to over $90^{\circ} \mathrm{F}$ in the summer. There are about 2,000 hours of sunshine each year. The drought effect of these warm dry summers on the site is also accentuated by frequent westerly winds. This site was chosen in preference to the dry hills themselves because it was accessible to Palmerston North, easily cultivated, and because of the excellent collaboration from the farm manager, D. Stevenson.

It was decided to concentrate at first on the familiar pasture species, in the hope of being able to find within these species either new varieties already naturally adapted to growing in dry conditions, or genes themselves that might then be transferred to existing New Zealand varieties. Other species, such as browntop, ratstail, sweet vernal and Notodanthonia, which are perhaps more common, more persistent, and even more productive in the dry regions, were not included in this first experiment. It was felt that these species had less long-term potential, in the sense that pasture fertility and management in these regions should gradually increase towards a ryegrass-white clover standard.

Accordingly, the site was planted in autumn 1967 with a large range of ryegrass, cocksfoot and Phalaris lines, Clovers were also planned, but could not be sown at the right time because of bad weather. Since winter growth, as well as summer growth, was a breeding objective, these lines were assembled from a range of overseas countries and climates. Collections made within New Zealand were also included, as well as control lines of 
known behaviour. The seed was germinated at Palmerston North and the seedlings were planted on the site at $2 \mathrm{ft}$ spacings. The ryegrass block contained 12 perennial and 12 short-term lines, each line having four replications of ten plants. The cocksfoot block contained five such replications of 38 lines, and the Phalaris block contained six replications of 78 lines. All 7,740 plants were scored by eye for growth on a 0 to 5 scale each season, and notes were also taken of unusual heading behaviour and disease susceptibility. After each growth note the block was grazed by sheep, trimmed by mowing if necessary, and cultivated between the rows. This, lax grazing pressure allowed the plants to express their full growth potential, which, in an experiment where large differences between lines are expected, is usually quite a good indication of their relative performance in swards (Rumball, unpublished data),

\section{RESULTS}

\section{SHORT-TERM RYEGRASSES}

All lines died during the first summer. Growth notes taken in early spring and early summer showed the best lines to be the New Zealand varieties, 'Grasslands Manawa', 'Paroa', and 'Tama', already available to farmers, plus an experimental population of tetraploid Italian bred by Dr P. C. Barclay. The overseas lines were often significantly poorer, having been bred for local use in Aberystwyth, Holland, France, Italy and U.S.A. They also tended to flower earlier.

\section{Perennial Ryegrasses}

The unusually severe drought in March-April 1968 killed many plants, and the following summer killed most of the remainder (Table 1). In all seasons, the best lines were again those bred in New Zealand, and mostly already available. Amongst these, however, was a line significantly better than all others in most seasons. This particular line was derived by Dr Barclay from a natural ecotype growing on a farm at Mangere, near Auckland. Its superiority was due partly to a lower mortality and partly to greater production from those plants remaining. A study of this line is warranted to find out exactly why it is so much better than the others. 
TABLE 1: RELATIVE GROWTH SCORES IN PERENNIAL RYEGRASSES BEFORE AND AFTER SUMMER 1967-8.

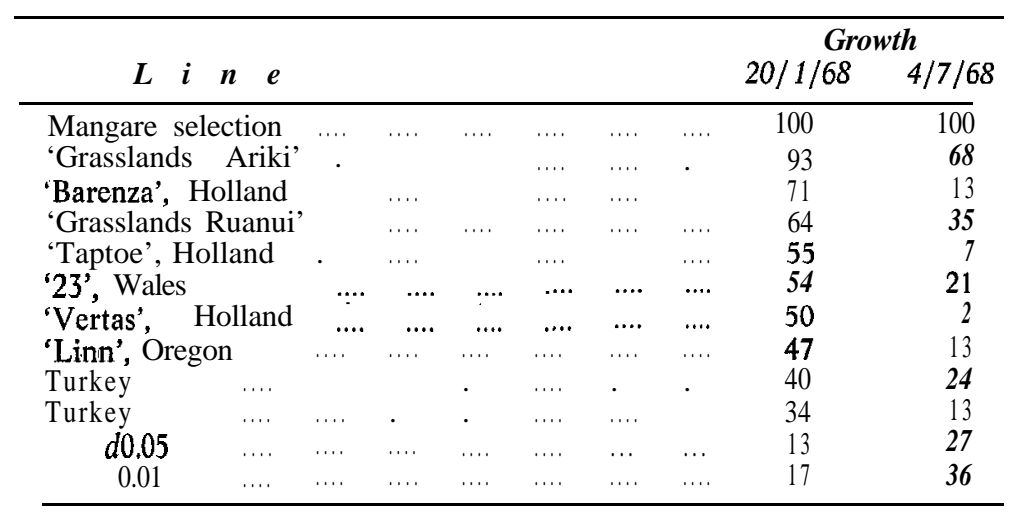

\section{COCKSFOOT}

Nearly all plants dried off and did not grow in February and March of either summer. Many were also attacked by a leaf rust. However, most of these plants recovered each autumn, except for some of the lines from Turkey, Portugal and Australia. Relative growth scores for all lines in the most recent summer and winter are graphed in Fig. 1. With only one exception (from Carentan, France), overseas lines were poorer than New Zealand ones in every season, and were significantly poorer than even the worst New Zealand line in all seasons except the first spring. The best lines each summer were derivatives of 'Grasslands Apanui', particularly a new selection bred by L. B. Anderson at Palmerston North. In winter, however, the superior lines came from hybrids or backcrosses between Apanui and Mediterranean material, being bred by Dr Barclay with the aim of transferring genes for winter growth into the currently available Apanui and selecting for greater persistence.

\section{PHALARIS}

Although other species were included in the experiment, only $\boldsymbol{P}$. tuberosa gave promising results and will be discussed here.

Few of the Phalaris lines made much growth in either summer or winter, but very few plants died out or became diseased. The 78 lines originated from 13 countries and showed a large range of growth and heading behaviour. However, two basic seasonal growth patterns could be sorted out. These patterns are shown 
in Fig. 2 by a representative line from each group, The scores of these lines are given for each growth note, relative to the mean score of all 18 New Zeaiand lines $(=100)$, which generally behaved alike.

The following main points can be made.

(1) The line from Libya had significantly poorer growth than the New Zealand standard in early and late summer of both years. However, its winter growth was significantly better than

\section{ORIGIN}
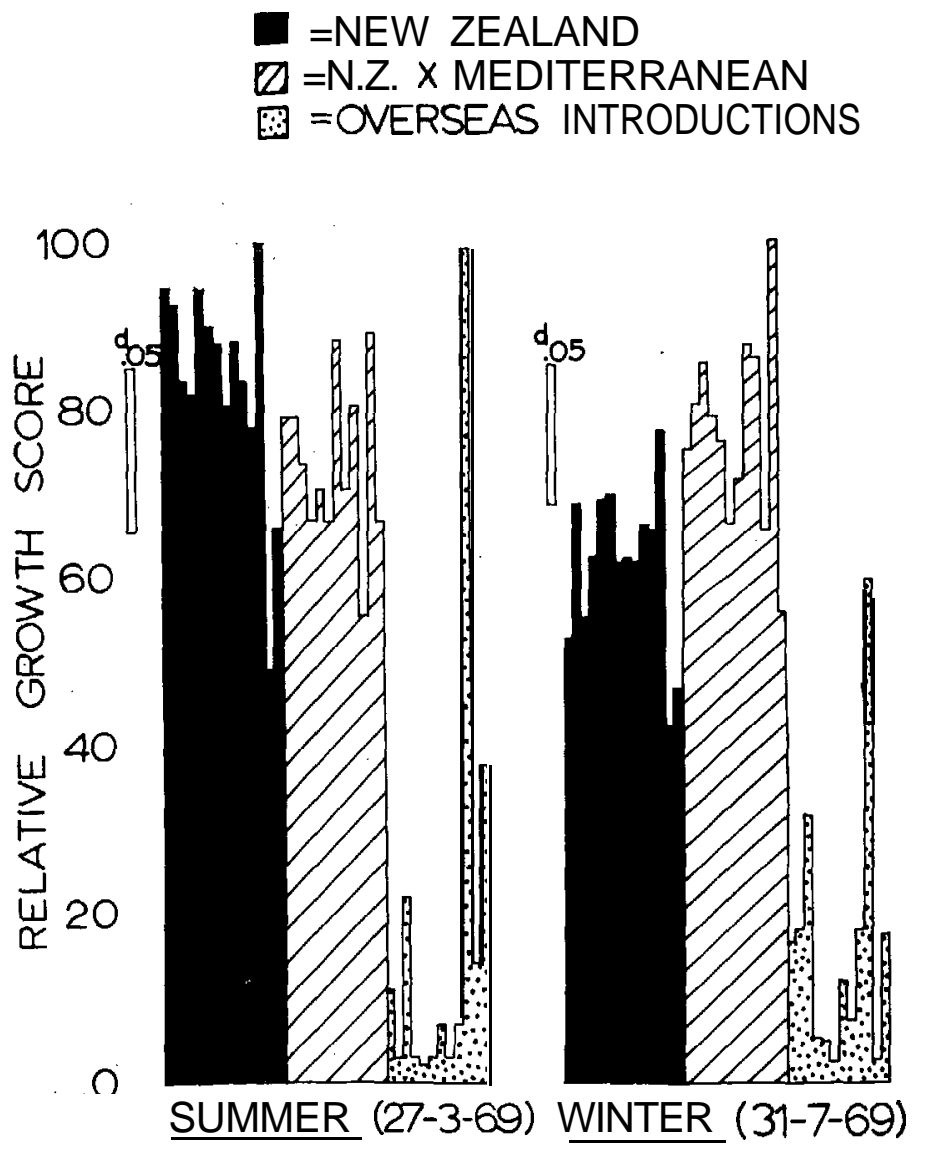

FIG. 1: Relative scores in all cocksfoot lines for growth in summer $(27 / 3 / 69)$ and winter $(31 / 7 / 69)$. 


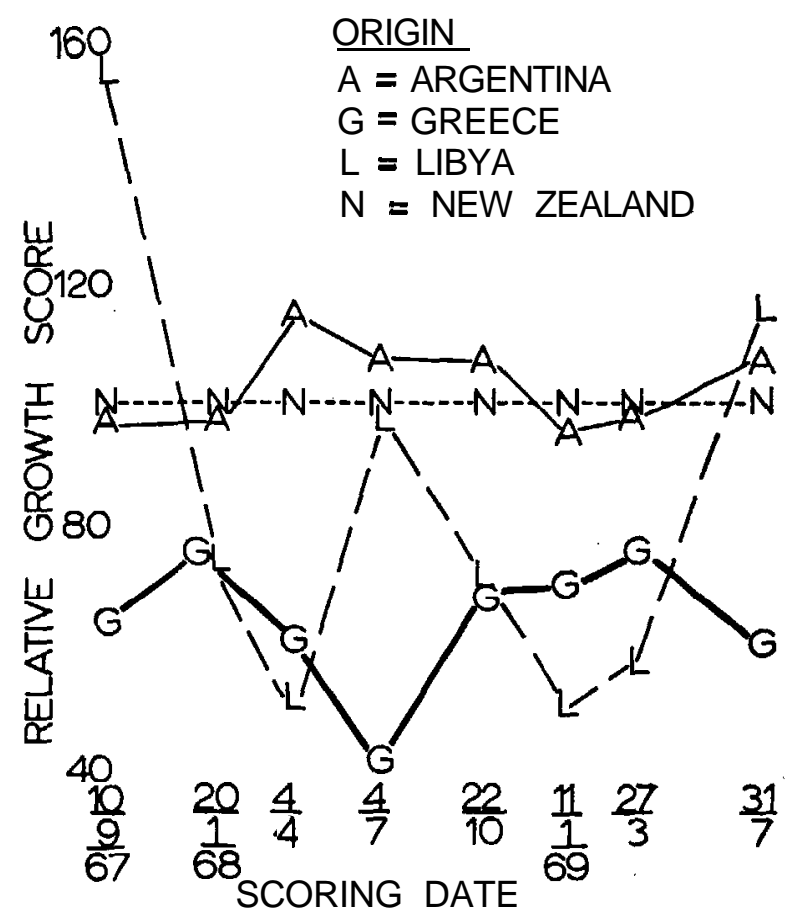

Fig. 2: Seasonal growth patterns in Phalaris tuberosa, relative to the mean score $(=100)$ of all New Zealand lines.

the standard in the first year (10.9.67), and not significantly different in the second (4.7.68) and third (31.7.69) years. The line is typical of those from Algeria, Israel, Morocco, Portugal, Spain and Turkey - i.e., from countries bordering the Mediterranean Sea. These are countries where the climate is very hot and dry in the summer. and native plants have evolved the pattern of growing in the wet and mild winter, seeding and becoming dormant in early summer. Such lines evidently retain this behaviour in New Zealand, even though our summers are less severe.

(2) The line from Greece had its relatively greatest growth in the summer notes, except the one on 4.4.68. This line originated in northern Greece, where the summer is less severe and the growing season covers 9 to 10 months (Cooper and McWilliam, 1966). It appears to repeat this behaviour in the Wairarapa, as 
also did lines from Argentina and northern Italy, though to a lesser extent.

(3) Of the thirteen countries represented, only Argentina (mean score of its three lines is shown in Fig. 1) and Italy consistently equalled or surpassed the New Zealand standard, and would warrant more intensive collections. However, it would certainly be worth while to attempt to transfer the genes responsible for winter growth to New Zealand material, and virtually any of the Mediterranean lines might be used.

(4) Although the lines from any one country generally showed the same seasonal behaviour, some lines were often much better than others at all seasons. This was particularly the case with Portuguese material, the eleven lines of which covered almost the whole range of rankings. Unfortunately, too little was known about the precise origins of these lines to show why these were so varied; New Zealand lines consistently spanned the top half of the rankings, with the best material coming from collections made near Thames and Linton. However, Australian lines also performed exceptionally well at particular seasons, those scoring highest in winter being derived from a large gene pool of Mediterranean material, and those scoring highest in summer being derived by hybrids between Australian commercial $P$. tuberosa and a summer-growing species, P. arundinacea. Both types were bred by CSIRO at Canberra.

\section{DISCUSSION}

Because of some promise shown in the Wairarapa and other regions, the Mangere selection of perennial ryegrass is being seed-increased and should be tested in more detail. The cocksfoots will be left in their present block for another summer in the hope of showing greater persistency differences than they have so far.

Th Phalaris results are sufficiently encouraging to continue selection, and in early 1969 the Wairarapa project moved forward another stage. Forty of the most promising lines and more recent collections of Phalaris were broadcast at $12 \mathrm{lb}$ per acre in replicated plots $8 \mathrm{ft} \times 4.5 \mathrm{ft}$. These plots will allow assessment under more realistic farming conditions, with greater pressure from grazing and greater competition for soil moisture. They will be assessed for production, persistence and palatability (the latter often being very low in some lines of Phalaris) .

As the plant breeding programme becomes more sophisticated in this way, it will call for more attention and facilities. Col- 
laboration between DSIR and the Department of Agriculture in such a programme is most important, and in the present case has already been highly rewarding. The later stages of testing should move on to dry hill sites and involve detailed measurement of the environment itself as well as of the plants. At the same time, a laboratory research programme should be started, aimed at learning precisely which are the characters of a plant that enable it to persist and produce in dry conditions, and whether these characters are heritable. Precise knowledge of this type enables much more efficient selection of plants.

\section{REFERENCES}

Cooper, J. P.; McWilliam, J. R., 1966: J. appl. Ecol., 3: 191-212.

Corkill, L., 1957: Agr. Rev., 1-7.

Report, 1968: Economic Survey of Wairarapa. Dept. Ind. Comm. 314 pp.

\section{DISCUSSION}

Asked about the origin of Mangere ryegrass, Rumba11 replied that it was an ccotype found on Mr Trevor Ellet's property near Mangere. The plants tested had come from a selection made from this ecotype.

Cullen suggested that tall fescue should perhaps be brought into a selection programme such as was being used for ryegrass, cocksfoot and phalaris. Rumba11 stated that work, was being carried out on tall fescue by Grasslands Division and much of the material would be tested in the Wairarapa.

To a question from Langer .regarding the testing of plants offered by farmers, Rumba11 said that any promising material would be tested. The possibility of reward was too great to be missed.

Smetham commented that it appeared as if the breeding of regional varieties might be developed. He also asked if plant introduction could be useful. Rumba11 replied that, where evidence showed that regional material could be produced without difficulty, it would be, for example, species at Kaikohe. He agreed that the plant introduction service must be continued and on a larger scale, particularly if the work in the Wairarapa was to be expanded. 